\title{
Effects of corporate governance on high growth rate: evidence from Vietnamese listed companies
}

\author{
Quoc-Viet Phama*, Thu-Hoai Hoa ${ }^{a}$, Duc-Huy Pham ${ }^{a}$ and Hong-Ron Nguyen ${ }^{a}$
}

${ }^{a}$ University of Finance-Marketing, Ho Chi Minh City, Vietnam

\section{A B S T R A C T}

\begin{abstract}
High-growth firm is the research object of economic and business studies, because of its important influence on job creation, innovation, and tax revenues increase for the nation. This paper is designed to find some empirical evidence on the role of corporate governance on the firm's growth, thereby providing some policy implications for improving corporate governance activities in practice. Using a sample of 241 listed companies on Vietnam's stock market in the period 2008-2017, divided into 2 groups: high-growth firms and non-high-growth firms and applying a GMM regression with the dependent variable as 3-year compound growth rate, the study finds evidence of factors affecting the growing ability of corporate governance, namely: the ownership structure, the characteristics of the Board of Directors (size, independence, gender, non-executive member, experience), and the characteristics of the CEO (age, educational level, ownership, duality).
\end{abstract}

\section{Introduction}

The highly influential research work of Birch (1979) shows that high-growth small companies play a very important role in the economy in creating new jobs. Since then, there have been increasing interest from researchers and policymakers on highgrowth small businesses. An interesting discovery concerning high-growth companies is that they not only create new jobs but also manage to survive better than non-high-growth companies (Davidsson, Kirchhoff, Hatemi-J, \& Gustavsson, 2002). Subsequent research has also found that high-growth companies belonged to heterogeneous groups (for example, Delmar, Davidsson, and Gartner (2003)). Although many studies have been done on determinants of growth by large firms, it is still known a little about small and medium-sized firms, especially manufacturing firms (see, for example, Raymond, Bergeron, and Blili (2005)). On the other hand, previous research on the growth of a small firm is diversified in research fields. Some researchers point out the importance of individual administrators and their characteristics (Noel (1989); Halikias and Panayotopoulou (2003)). Other researchers focus on the company' structure - such as age, size, industry, market, legal form, location and ownership (Davidsson et al., 2002) - or networking (Beekman \& Robinson, 2004), and some others focus on external environments such as policies, laws. One of the internal factors affecting the growth of the firm is corporate governance (Wirtz, 2011). In a complex business world, corporate governance is seen as a mechanism to maximize firm value. Many empirical studies have shown a causal relationship between corporate governance and market value and business growth, not only in a specific country but also in cross-national researches (Ramaswamy, Ueng, \& Carl, 2008). A good corporate governance system leads to better access to capital, improved work performance, and risk reduction. However, the implementation of effective corporate governance systems is also costly. Technology constraints, lack of financial and business knowledge, and the cost of implementing and communicating corporate governance policies across the organization are the important barriers that many companies, especially small firms, face. Vietnam is known as a transitional, small-scale 
economy, but with high economic openness. Corporate governance in Vietnam has only been placed into law since 2007 and is in the process of completion. The corporate governance rules are mainly applied to public companies and listed companies, with basic principles such as fairness, publicity, and transparency. The majority of firms in Vietnam are small and mediumsized firms (SMEs), not public companies. The life cycle growth model shows that such firms inevitably change to public companies and apply corporate governance rules. The study of the relationship between corporate governance and the growth of firm based on a sample of public listed companies, especially high-growth ones, on the one hand, can contribute empirical evidence for research on high-growth small firms, and, on the other hand, can give guidance and suggestions for listed companies.

The remainder of this article is organized as follows: Section 2 is about theoretical background and Section 3 literature review. Section 4 presents the study design and Section 5 empirical studies. Section 6 is "Conclusions and Implication".

\section{Theoretical background and literature review}

\subsection{High growth firm $(H G F)$}

Research on firms shows that all go through different growth stages of the life cycle (Gupta, Guha, \& Krishnaswami, 2013). Although the terms used may vary, the events that each firm pass are still more or less similar. Most researchers argue that every firm has to start, then grows while facing different challenges and crises, and ultimately saturate and decline. The interest in high-growth companies is driven by the fact that they are seen as important economic driving forces, spreading innovation and creating jobs (Hölzl, 2013). Empirical studies have shown that a small number of high-growth companies create the majority of new jobs (Almus, 2002). This fact is not surprising because it is closely related to the definition of high-growth companies as the ones with the best growth performance. One of the challenging issues when researching high-growth companies is how to define this specific type of company. There are many definitions of HGF, which makes it difficult to compare the results of different studies. A fairly common definition in HGF studies is the Birch index (Almus, 2002). The Birch index (BI) is calculated by the absolute growth of labor multiplies with the relative growth of labor:

$$
B I=(E 1-E 0) \cdot \frac{E 1}{E 0}
$$

where E1 and E0 is respectively the number of employees at the end and the beginning of the study period. An HGF is firm in the top $5 \%$ or $10 \%$ according to BI distribution. Hoxha and Capelleras (2010) summarized the measurements used in empirical studies of firm growth. The previous authors, in spite of using different terms to refer to firm growth, often used the definition of revenue growth rate of at least 20-25\% annually for a period of 3-5 years, namely: Siegel, Siegel, and Macmillan (1993), Storey (2000), Birch and Medoff (1994). Some other authors are interested in the top 10\% firms of labor growth, such as Davidsson et al. (2002), Davidsson and Delmar (1997), Almus (2002), and Schreyer (2000).

\subsection{Determinants of firm's growth}

Because there is no single theoretical model that explains high growth, Storey's hypotheses Storey (2000) is often used by successive researchers to model and explain the high growth of firms. According to Storey, there are three groups of factors that affect firm growth, including start-up characteristics (entrepreneur), strategic factors and company characteristics. In general, Storey emphasizes the elements of the internal environment. Glancey (1998) summarizes the previous relevant literature and provides a number of hypotheses that may be related to the relationship between size, age, location and profitability and the growth of the firm.

\section{Size and firm growth}

A positive relationship between firm size and growth can be anticipated if larger companies achieve their size because they are managed by entrepreneurs with business acumen and higher manageability. This relationship can also be achieved when a company is depleted of the best opportunities for growth, and growth through diversifying its portfolio.

Age and firm growth

A positive relationship between company age and growth can be achieved if long-standing companies have their benefit from economies of scale by learning from experience. These companies can also have their benefit from a reputable effect, allowing them to achieve a higher margin profit on revenue. On the other hand, older companies may have developed practices that are inconsistent with changes in market conditions, in which case the inverted relationship between age and growth can be observed.

\section{Location and firm growth}

Firms in rural areas may have higher profit rates and growth speed than firms in urban areas if due to a more competitive cost of production factors (especially land and labor). Urban companies may also face with spatial constraints that limit the extent 
of expansion. On the other hand, companies in urban areas may be better located (closer to their markets) to take advantage of changes in market conditions, which may have higher growth speed. This is particularly useful when the economy gradually relies on traditional production factors and increases the knowledge contained in the structure cost.

\section{Profitability and firm growth}

If small-scale firms often rely on retained profit as the main source of funding to expand to avoid external donors from engaging in company activity, then a positive relationship between profitability and growth can be expected. In addition, if the enterprise has an outstanding margin profit, it is easier to absorb external funding. Higher growth speed can lead to higher profit by effectively enhancing the learning effect. On the other hand, if the company tries to grow beyond the speed it can manage, the dynamic economies of scale can be a barrier. If growth is achieved through cutting profit in existing markets, instead of diversifying into new markets, the relationship between growth and profitability may also be negative. Gupta et al. (2013) suggest that the growth of a firm can be determined from four theoretical perspectives: resource-based perspective, strategic adaptation perspective, motivation perspective, and configuration perspective. When the focus of firms is on resources such as business expansion, financial resources, trained staff, etc., growth will be studied from a resource-based perspective. Studies of growth using a strategic adaptation perspective as a long-sighted perspective will focus more on energy coordination, the complexity of structure and control mechanisms. The motivation perspective focuses on individuals and their actions. Finally, the configuration perspective related to the growth process focuses on management issues and how they can be handled at different growth stages. These authors have summarized two theoretical frameworks for research on the growth of the firm. The first theoretical framework determinably estimates that the growth path can be linear, sequential, deterministic and invariant. There are many different ideas about determining the growth path of a firm in a predictable way starting from birth, survival, success, developing, maturing and then reinventing or ceasing existence. The remaining theoretical framework suggests that there may be sudden changes in the path of growth, especially in small firms. Previous studies have shown that due to unpredictable interventions such as knowledge and technology, absorbing capacity, founder's decisions, and competitive environment, growth stages may be heterogeneous in small firms. Since then, Gupta et al. (2013) proposed to consider the impact of external environmental factors on the growth model of small and medium firms, in addition to the internal environmental factors that the previous authors verify.

\subsection{Corporate governance and its impact on the growth of a firm}

The concept of corporate governance is not new - it has been around for a long time. However, with the collapse of large companies such as Enron, WorldCom, the firm community, under increasing supervision, has refocused on the importance of corporate governance. The study of these failed companies indicates the absence of consistent policies, control procedures, guidelines and mechanisms to ensure accountable and fiduciary responsibility (Ramaswamy et al., 2008). A corporate governance structure that details the distribution of rights and responsibilities with the number of different participants in the company and outlines the rules and procedures for making decisions on company issues. Shleifer and Vishny (1997) argue that corporate governance can be more narrowly defined as instruments that ensure the maximum. In a complex business world, corporate governance is seen as a mechanism to maximize corporate value. Many empirical studies have shown a causal relationship between corporate governance and market value, not only in one country but also in multinational research (Ramaswamy et al., 2008). A good corporate governance system often leads to better access to capital, improve performance and reduce risk. However, the implementation of effective corporate governance systems is also costly. Technology constraints, lack of financial and business knowledge, and implement cost and communicating corporate governance policies across the organization are important barriers that many companies, especially small firms, are facing. According to Charreaux (2008), the corporate governance system adopts specific mechanisms and market pressure, plus the characteristics of the board of directors that will influence the decision-making process of the firm, thereby affecting the performance of a firm, including firm growth.

There are some theories explaining this mechanism of action, the most important of which are:

Agency theory: This theory was originated from economic theory and it was developed by Alchian and Demsetz (1972), and by Jensen and Meckling (1976). This theory is based on the imperfect information base between the owner and the agency when the representative knows more than the owner about the work he/she must do, resulting in a conflict of interest on both. The agency may not be in the best interests of the owner as he/she has an information advantage and has more other benefits than those of the owner. That will lead to the opportunistic behavior of the agency and is called by the agency theory the opposite choice. To mitigate this risk, either the owner uses the information system of expenditure rules, reporting procedures, administrative levels; or the owner authorizes the assignment to the representative and controls the performance and outcome of that work through a contract. However, the agency's opportunistic behavior will still occur when he/she fails to comply with the terms of that contract, which is called by agency theory moral risk. Imperfections and asymmetric information between the owner and the agency will incur the representative costs. The agency theory was born on the basis of ensuring the interests of the owner to focus on research and develop a contract in order to reduce agency costs. Agency cost is the type of cost to maintain an effective agency relationship. Agency theory defines agency cost as the sum of all types of costs, such as monitoring cost, to monitor the activities of the agency, such as audit cost; bonding cost of setting up an organization which can minimize unwanted management behaviors, such as appointing external members to the board 
of directors or reorganizing company organization system; and residual loss or opportunity cost when shareholders hire agency and are forced to make restrictions, for example, losses due to agency abuses their assigned rights for self-interest; losses due to the setting up of the voting rights of shareholders on specific issues, losses from measures to control the agency's activities.

Stewardship Theory: agency theory cannot solve some situations where the manager's interests do not conflict with the owner's interests, or the manager considers his interests with the benefit of the owner. At this point, the manager will achieve its goals by helping the organization achieve its common goals. Stewardship theory hypothesizes that managers are not influenced by individual goals, but by the motivations associated with the owner's goal. This theory argues that the CEO can operate effectively not only because they have the capacity, but also that they have the same goals as the beneficiaries (Muth \& Donaldson, 1998). Scholars who support stewardship theory also introduce the concept of "homogeneous goals" of manager and company. At that time, managers believe that the success of the company is their own success and this will contribute to building their personal image. A manager who is consistent with the company will work for the company's goals, solve company problems and overcome barriers that hinder the fulfillment of the assigned task. When individuals identify with the company, they often exhibit cooperative, altruistic and self-conscious behaviors (O'Reilly \& Chatman, 1986). Therefore, managers who identify with the company are motivated to help it (the company) to succeed and should be given the right to do their job because this will allow them to use their competencies to promote the success of the company.

Resource Dependency Theory: Burgel, Fier, Licht, and Murray (2000) were the first to build the foundations for the resource theory of firms. This theory refers directly to the board of directors' ability to bring resources to the company, resources that can be considered as strengths or weaknesses of a given company (Wernerfelt, 1984). Hillman and Dalziel (2003) states that when an organization appoints an individual to the board of directors, they hope that the individual will support the organization. They assert that four main benefits can be provided by board members: (1) advice and consultancy, (2) prestige, (3) relationship with external organizations and company, and (4) preferential access or support from organizations outside the company.

Firstly, the board of directors' resource relates to providing advice and consultancy. Board of directors often consist of lawyers, financial agencies, senior management of other companies, economic experts, former government officials, and CEOs of other firms provide for the company significant expertise, experience and skill (Baysinger and Butler (1985); Gales and Kesner (1994)).

Secondly, the board of directors' resource relates to providing the legitimacy and reputation of the company (Daily and Thompson (1994); Hambrick and Crozier (1985)). Certo, Daily, and Dalton (2001) found that firms with higher effective performance of the reputation council will be valued higher at their initial public offering. This shows that the reputation of the board members can enhance the reputation and performance of the company.

Thirdly, the board of directors' resource relates to providing communication and information channels between the company and outside organizations. The board of directors' resource provides for the company timely and valuable information to reduce transaction costs when dealing with risks outside the company, thereby improving operational efficiency. Eisenhardt and Schoonhoven (1996) argue that the outside relationships of the CEO play an important role in developing future strategy and firm performance (Geletkanycz \& Hambrick, 1997). Rosenstein and Wyatt (1994) by using the event research method, the value of one company will improve when the CEO of one company is asked to join the board of another company.

Fourthly, the board of directors' resources can be useful in acquiring important resources from organizations outside the company, direct relationships that allow companies to secure the important resources, often based on more beneficial terms. Hillman, Keim, and Luce (2001) suggest that companies often invite important customers and suppliers to represent their board, to create more commitments and involvements from these stakeholders (Baysinger \& Butler, 1985). Similarly, startups or new ventures often bring venture capitalists to their board, perhaps not only to access capital but also to their benefit, as well as to gain legal (Fried, Bruton, \& Hisrich, 1998). Resource-dependent theory shows that the supply of resources by council members is directly related to firm performance. Resources help reduce the reliance between the company and external risks, reduce transaction costs (Hillman \& Dalziel, 2003). Human capital theory: OECD (2010) introduced the concept: "Human capital is the knowledge, skills, competences and potential attributes of each individual, contributing to economic prosperity, social cohesion and himself'. This concept emphasizes that human capital is in a continuous process of change from the moment of birth to the end, and it is implied that not only are skills, techniques, cognitive abilities, but also implied human health because, without health, individuals cannot devote with the qualities they possess. This theory has special reference to education made by (Becker, 1975). He emphasized investing in human capital, arguing that the human capital theory has changed the way we understand education: education has become an investment thought to create personal value as well as enhancing the quality of the economic workforce.

For an enterprise, human capital is the labor force that involves the company's executive and production activities. Therefore, every employee in the company is required certain knowledge, skills and techniques in order to work in high productivity, which means the human resource must be invested in education and training to have the intellectual capacities, knowledge on industry-related fields of company, ability to practice in the fields of company and good health to satisfy requirements of 
company. No investment is more profitable than investing in humans, especially in education and training, so human capital (years of education and work experience) affects income. A company with a well-trained workforce, proper qualifications, and good health investment will be the first factor affecting the technology - technical level of that firm, which will help the firm to use it effectively for every physical capital investment, the company may not need to increase its physical capital investment but still can increase its income many times. In addition, human resources is also considered in some aspects: individual and social. Therefore, when considering the structure of human resources, at first, it must be its individual aspect including three elements: physical, intellectual and ethical, these three elements constitute the individual quality of human resources and directly affect the sustainable development of a firm.

Wirtz (2011) conducted research to explore the morphology and functions of corporate governance systems of HGFs. To explain the connection between corporate governance system and firm growth, the author built a model based on the proposed model of Charreaux (2008), in which corporate governance has the impact potential to the attitude of the executive through two levers: financial discipline and awareness. The author's assumption is that in the case of firm growth, corporate governance can play an important role in maintaining high growth rates through the widespread usage of cognitive leverage. The author proposes four components explaining the potential for firm growth as (1) a group of senior management; (2) board of directors; (3) venture capitalists; (4) the dynamism of the environment.

Jensen and Meckling (1976) proposed an agency theory to explain the conflict between shareholder (owner) and director (agency). The authors argue that the growth in the use of corporate form as well as the growth in the market value of established companies shows that, at least up to now, creditors and investors were not disappointed with the results, although agency cost existed in corporate form. They also claim the agency cost is real, like any other cost. The level of agency cost depends on the rule of law and the human ingenuity of making contracts. Both law and sophistication of modern companyrelated contracts are the product of a historic process, including strong incentives for individuals to minimize agency costs. Andersson and Tell (2009) conducted a review of articles related to the role of the CEO for firm growth in the top 6 scientific journals, summarizing the three main relationships identified between growth and, respectively, managerial characteristics, managerial intent, and managerial behavior or role.

\section{Literature review}

\subsection{Effects of corporate governance to the growth potential of the enterprises}

The research on the effects of corporate governance on the performance of the stock company (including the growth of corporate) until now has been implemented in two main directions. According to the first research direction, a formula for determining corporate governance rating has been set and this rating has been used as an independent variable in the research model. Representatives of this research direction are Ramaswamy et al. (2008), whereby the authors have developed a set of Corporate Governance Score, based on 10 components of the corporate governance system. However, in many different economies, the absence of secondary information, or the difficulty of obtaining primary information from companies resulting in difficulties in the corporate governance ranking. Therefore, some researchers individually examine the correlation between the variables that constitute a corporate governance system with operational efficiency, to detect predominant impact factors. The constituted variables which have been commonly considered so far are the ownership structure, the nature of the Board of Management and the nature of the Board of Directors. The ownership structure plays an important role in the corporate governance system because through it, the major shareholders can exercise control over the Board of Management (thereby controlling the company's business strategy) and the right to appoint and dismiss the CEO (thereby controlling the day-to-day operations of the company). Many experimental researches are trying to verify the effects of ownership structure on the ability of corporate growth. Daily and Thompson (1994) make an assumption that the ownership structure affects the strategic situation and thereby affects the growth of enterprises; however, the authors found no effects from the ownership structure to the growth rate. Konings (1997) studies this problem issue in transition economies and provides evidence of the positive impact of private ownership on growth, and also points out the uncertainty of equitization and state ownership on growth. Bjuggren, Daunfeldt, and Johansson (2010) follow the research direction of private ownership through analyzing the ownership of the company - family or non-family owned company - whether it is important to become HGF or not; the results show that family ownership reduces the probability of high growth, and changes ownership from family to non-family which increases the probability of becoming HGF, while the change from non-family to family ownership reduces the probability of becoming HGF. Recently, the research question has arisen how the independent ownership structure with founding shareholders affects the growth. However, the experimental results are inconsistent: while Schreyer (2000), Delmar et al. (2003) found that the ownership of founding shareholders is positively correlated with the growth potential, Brüderl and Preisendörfer (2000) found the opposite result. The research on the relationship between the characteristics of the Board of Management and the growth rate of the company is also concerned by many researchers, because of the importance of the Board of Management to the company's business strategy and the ability to control and direct the CEO's operations from this agency. Daily and Dalton (1992) conducted research on the relationship between corporate governance and corporate performance of startups. The authors provided the basis for assumptions on the effects of the CEO, duality of CEO and the Board Chairman, all members of the Board on the corporate performance, including growth potential. The research samples consisted of 100 listed companies ranked as the fastest growing in the United States in May 1990. Research results show that the duality of the CEO and 
the founder helped to increase the performance, but this dual position has no significant effect on the composition of the Board. In addition, the presence of outside members of the Board helps to increase the performance of HGFs. Deakins, O'Neill, and Mileham (2000) reinforce this conclusion by providing evidence of the positive impact of outside members of the Board on the growth of small companies in Scotland. Ramaswamy et al. (2008) tested the hypothesis of the ability of corporate governance to maintain corporate growth in 4 aspects: equity, responsibility, transparency, and accountability. The authors used the corporate governance index which is configured from 10 factors with equal weight: the structure and composition of the Board, the operation and performance of the Board, the contributions of the Audit Committee, strategies - plans and supervision, risk management and compliance, corporate ethics, shareholder value creation, equity and transparency in information disclosure, accountability to related parties. Through the sample S\&P500, the research results show that the new growth companies have a lower corporate governance score, those that survive after growth have a higher corporate governance score, helping to increase resonance for growth. The regression results also show that, while the development of the Board and the role of the Audit Committee affect both groups of companies (new growth and survival), other factors such as corporate ethics, shareholder value creation, transparency in information disclosure and better accountability for surviving companies. An interesting research direction related to corporate governance is the gender of senior leaders. Steffensmeier and Allan (1996) argued that female managers are often afraid of risks, thus taking actions that are detrimental to shareholders. Smith, Smith, and Verner (2006) found evidence of a positive correlation between the gender of senior leaders (in the Board of Management and Board of Directors) and corporate performance on the sample of 2,500 largest-size enterprises in Denmark in the period of 1993-2001.

There are much researches on the role of CEO to explain the growth of enterprises such as Daily and Dalton (1992), Donaldson and Davis (1991), Hoxha and Capelleras (2010), Navaretti, Castellani, and Pieri (2014). While Daily and Dalton (1992), Donaldson and Davis (1991) tried to connect between the CEO and the Board, other authors only studied the role of CEO separately. Daily and Dalton (1992) argued that founding CEOs tend to be more open (rarely concurrently Board Chairman and willing to use outside members), resulting in a positive impact on business growth. Donaldson and Davis (1991) provided the opposite evidence, which is a positive correlation between duality and growth rates, and interpret this result based on management theory rather than representative theory. Hoxha and Capelleras (2010) on the results of interviews with CEOs in Kosovo, provided evidence of a negative correlation between the degree (university diploma) of CEO and corporate growth. Navaretti et al. (2014) provided evidence of high growth related to young CEOs.

\subsubsection{Factors affecting the ability of corporate growth}

Many researches have tried to identify the main factors affecting the growth of enterprises. These researches can be divided into two main schools: the first refers to the effects of corporate size and age on growth, while the second refers to the effects of variables such as strategy, organization, and the outside environment. Glancey (1998) provided evidence of a positive correlation between firm size and growth. While Almus (2002) and Moreno and Casillas (2007) argued that the smaller the firm size, the higher the growth rate. Regarding the age of the company, most of the empirical evidence (Glancey (1998); Almus (2002); Navaretti et al. (2014)) agreed that new companies will have higher growth rates. However, Mateev and Anastasov (2010) were among the few authors who could not find a correlation between the age and growth of the company. Many authors seek internal environmental factors affecting the ability of corporate growth. The factors of excess resources and financial situation are supported by many authors such as (Glancey (1998), Voulgaris, Asteriou, and Agiomirgianakis (2003), Moreno and Casillas (2007), Mateev and Anastasov (2010). Hambrick and Crozier (1985) provided evidence of the role of strategy and internal governance on corporate growth such as vision, governance and process hierarchy, employees, equity ownership of employees and executives. Finally, Gupta et al. (2013) pointed out the importance of external environmental factors in influencing corporate growth, including demographics, social, cultural-ethical environment, political environment, financial environment, etc. Up to now, although there have been many pieces of research on corporate governance, from the scientific data that the authors have access to, the researches on corporate growth which has been published are very limited. The researches showing the relationship between corporate governance and corporate growth are even rarer. Võ Hồng Đức and Phan Bùi Gia Thủy (2013) quantified the relationship between corporate governance and corporate performance in Vietnam with a sample of 122 companies listed on Ho Chi Minh City Stock Exchange in the period of 20062011. The research results show that the factors of corporate governance such as female members of the Board, duality, experience of the Board and remuneration of the Board have a positive impact on the performance of the company; while the size of the Board has a negative impact on the performance of the company. The most recent is the research of Phạm Quốc Việt and Lê Quốc Thành (2016) which explored the key success factors of fast-growing enterprises in Vietnam. The success factors were discovered through an expert test method that has re-tested on the HGF sample in Vietnam (FAST500). The research results show evidence of the relationship between the characteristics of the Board and the corporate growth, namely the positive correlation of age, professional level and gender (female) of the Board and the ability of corporate growth. Through the survey, it can be seen that the research on corporate growth in Vietnam is not much, particularly and subjectively, there has been no research on the effects of corporate governance on the ability of corporate growth to be discovered. In-depth research of this relationship, on the one hand, can lead to proposals to improve corporate governance activities to support the ability of corporate growth, and on the other hand, can be the basis for policies to support HGF in Vietnam. Therefore, the authors expect to conduct a detailed test of the effects of corporate governance on the ability of corporate growth in Vietnam, in order to supplement practical evidence for this research direction. 


\section{Study design}

\subsection{Data source}

The research data focuses on HGFs in Vietnam, listed on HSX and HNX, in the period of 2008-2017. The research data is taken from financial statements (for dependent variables, control variables), annual reports (for independent variables) of the above companies. The research period lasted 10 years, from 2008 to 2017. The research samples are based on the financial statements of companies listed on the HSX and HNX including enterprises from many different sectors of the economy; which screened according to the following criteria:

- Firstly, the companies selected in the sample must operate continuously during the research period.

- Secondly, enterprises in the financial sector such as banking, insurance, financial services are excluded from the samples because the accounting method and indicators on financial statements of these types of companies are relatively different from the rest of non-financial companies, so it will affect the research results. The research samples were divided into two groups: High growth firms (HGF) and non-high growth firms (non-HGF). Criteria for identifying high growth firms: Inheriting the research of Siegel et al. (1993), companies with double revenue greater than $25 \%$ for 3 consecutive years are classified as HGF. The research period of the article in the period of 2008-2017, because of the calculation of double revenue (according to CAGR formula), the data for revenue growth of companies is only from the period of 2011-2017. Thus, in this period, only companies with 3 consecutive years of double revenue greater than $25 \%$ will be classified as high growth firms (Although such companies may have double revenue of less than $25 \%$ or negative).

\subsection{Methodology}

\subsubsection{Hypotheses}

\section{Hypothesis 1: There exists a relationship between ownership concentration and corporate growth}

This hypothesis is based on the Management Theory and Representation Theory. According to Charreaux (2008), the direct control of shareholders is a part of the corporate governance system, affecting the attitude of executives (according to the argument of Wirtz (2011)), thereby affecting the corporate performance, including growth potential. This hypothesis is supported by Schreyer (2000), Delmar et al. (2003), Brüderl and Preisendörfer (2000), Bjuggren et al. (2010).

\section{Hypothesis 2: There exists a relationship between the characteristics of the Board and corporate growth}

This hypothesis is based on the Representation Theory and the Theory of Human Capital. According to Charreaux (2008), the Board is a part of the corporate governance system, affecting the attitude of executives (according to the argument of Wirtz (2011)), thereby affecting the corporate performance, including growth potential. This hypothesis is consistent with the previous empirical evidence of Daily and Dalton (1992), Ramaswamy et al. (2008).

\section{Hypothesis 3: There exists a relationship between the characteristics of the CEO and corporate growth}

This hypothesis is based on the Representation Theory and the Theory of Human Capital. According to Wirtz (2011), the widespread use of awareness levers for senior managers in the decision-making process affects corporate performance, including growth potential. This hypothesis is supported by Daily and Dalton (1992), Navaretti et al. (2014).

\subsubsection{Model specification}

The model used by the research team basically inherited the research of Moreno and Casillas (2007) for dependent variables and control variables, supplemented by Daily and Dalton (1992), Ramaswamy et al. (2008), Navaretti et al. (2014) for independent variables. The regression equation used: Growth potential $=\mathrm{F}$ (control variable, independent variable). Inheriting Moreno and Casillas (2007), to ensure the influence effect, independent variables and control variables are taken with a 3year lag. The research team performed two regression equations:

Eq. (1) examines the relationship between the characteristics of the CEO and the ability of corporate growth:

$$
\begin{gathered}
\text { GROWTH }_{i t}=\alpha_{i t}+\beta_{1} \text { CEODUAL } L_{i t-3}+\beta_{2} \text { CEOSHARE }_{i t-3}+\beta_{3} \text { CEOAGE }_{i t-3}+\beta_{4} \text { CEOEDU }_{i t-3}+\beta_{5} A G E_{i t-3} \\
+\beta_{6} \text { SIZE }_{i t-3}+\beta_{7} \text { SOLV }_{i t-3}+\beta_{8} L I Q_{i t-3}+\beta_{9} T U R N_{i t-3}+\varepsilon_{i t}
\end{gathered}
$$

Eq. (2) examines the relationship between the characteristics of the Board and the ability of corporate growth:

$$
\begin{aligned}
& \text { GROWTH }_{i t}=\alpha_{i t}+\beta_{1} \text { BLOCK }_{i t-3}+\beta_{2} \text { BSIZE }_{i t-3}+\beta_{3} \text { BOU }_{i t-3}+\beta_{4} B N D E P_{i t-3}+\beta_{5} B G E N D E R_{i t-3} \\
& +\beta_{6} \text { CEODUAL } L_{i t-3}+\beta_{7} A G E_{i t-3}+\beta_{8} S I Z E_{i t-3}+\beta_{9} S O L V_{i t-3}+\beta_{10} L I Q_{i t-3}+\beta_{11} T U R N_{i t-3} \\
& +\varepsilon_{i t}
\end{aligned}
$$


Firstly, the authors used in turn Pooled OLS, FEM and REM regression methods for three models, and conducted tests (F-test and Hausman-test) to choose the model for optimal results. The authors then checked the possibility of violating regression assumptions such as Multicollinearity, Variance, and Endogenous. However, the article used panel data, and panel data is related to both spatial and temporal aspects, so it will encounter problems that often appear in spatial data, such as variance, endogenous and temporal data, such as correlation. To overcome endogenous, the author used the GMM method, which is commonly used in the estimation of linear dynamic table data or the table data which violates HAC (Heteroskedasticity and Autocorrelation) characteristics. Unlike the OLS method's goal of minimizing residual squares, the GMM method aims to minimize the Chi statistical value - square of the function including the appropriate moments and weight matrixes. Thus, by selecting the appropriate weight matrix (particularly, selecting tool variables), this method will overcome the phenomenon of correlation, variance and endogenous of the model. The appropriateness of the model will be demonstrated by the AR (2) test and Hansen-test.

\section{Empirical results}

\subsection{Descriptive statistics results}

The whole sample of research data after screening includes 241 companies in the period of 2008-2017, and independent variables and control variables were taken according to the 3 -year delay, resulting in a total of 852 observations (Table 1). Of which, the HGF group consists of 69 companies, 245 observations (Table 2); the NonHGF group consists of 172 companies, 607 observations (Table 3).

Table 1

Descriptive statistics (whole sample)

\begin{tabular}{|c|c|c|c|c|c|c|c|}
\hline VARIABLES & MEAN & MEDIAN & SD & MIN & MAX & SKEWNESS & KUSTOSIS \\
\hline GROWTH & 0.1012 & 0.0856 & 0.2534 & -1 & 3.2449 & 2.0287 & 2.9182 \\
\hline CEODUAL & 0.3320 & 0 & 0.4710 & 0 & 1 & 0.7134 & 1.5090 \\
\hline CEOSHARE & 0.0581 & 0.0099 & 0.1019 & 0 & 0.7285 & 2.5088 & 9.8196 \\
\hline CEOAGE & 49.1515 & 50 & 7.5110 & 24 & 71 & -0.2214 & 2.5431 \\
\hline CEOEDU & 0.1917 & 0 & 0.3937 & 0 & 1 & 1.5661 & 3.4527 \\
\hline BLOCK & 0.3319 & 0.3201 & 0.2062 & 0 & 0.9038 & 0.1464 & 2.0816 \\
\hline BSIZE & 5.1977 & 5 & 1.7613 & 0 & 11 & -1.0119 & 6.2317 \\
\hline $\mathrm{BOU}$ & 0.1460 & 0 & 0.2318 & 0 & 1 & 1.4012 & 3.7916 \\
\hline BNDEP & 0.2334 & 0.2 & 0.2435 & 0 & 1 & 0.6864 & 2.4780 \\
\hline BGENDER & 0.1453 & 0.1428 & 0.1599 & 0 & 1 & 0.8951 & 3.2776 \\
\hline AGE & 5.4494 & 5 & 3.0164 & 4 & 17 & 0.5362 & 2.9514 \\
\hline SIZE & 26.8052 & 26.6639 & 1.4603 & 20.0441 & 31.9220 & 0.3014 & 3.2923 \\
\hline SOLV & 2.5919 & 1.9538 & 1.6459 & 1.0018 & 9.7372 & 1.9242 & 6.7249 \\
\hline LIQ & 1.9237 & 1.4511 & 1.3873 & 0.1843 & 9.7864 & 2.4156 & 9.8823 \\
\hline TURN & 1.1667 & 0.9594 & 0.8746 & 0 & 5.9951 & 1.8316 & 7.7627 \\
\hline
\end{tabular}

Source: Authors' calculation from survey data

Table 2

Descriptive statistics (HGF group)

\begin{tabular}{|c|c|c|c|c|c|c|c|}
\hline VARIABLES & MEAN & MEDIAN & SD & MIN & MAX & SKEWNESS & KUSTOSIS \\
\hline \multicolumn{8}{|l|}{ HGF group } \\
\hline GROWTH & 0.2544 & 0.2547 & 0.3157 & -0.4075 & 3.2449 & 3.1066 & 2.9980 \\
\hline CEODUAL & 0.2573 & 0 & 0.4374 & 0 & 1 & 1.1101 & 2.2325 \\
\hline CEOSHARE & 0.0554 & 0.0091 & 0.1011 & 0 & 0.6053 & 2.7148 & 11.0501 \\
\hline CEOAGE & 47.4732 & 47 & 7.7670 & 28 & 69 & 0.1264 & 2.2981 \\
\hline CEOEDU & 0.1786 & 0 & 0.3833 & 0 & 1 & 1.6776 & 3.8143 \\
\hline BLOCK & 0.3058 & 0.2763 & 0.2020 & 0 & 0.9038 & 0.3295 & 2.3352 \\
\hline BSIZE & 5.2103 & 5 & 1.7908 & 0 & 10 & -1.1441 & 6.1397 \\
\hline $\mathrm{BOU}$ & 0.1275 & 0 & 0.2189 & 0 & 0.8571 & 1.5373 & 4.1393 \\
\hline BNDEP & 0.2096 & 0.2 & 0.2384 & 0 & 1 & 0.9213 & 2.9386 \\
\hline BGENDER & 0.1412 & 0.1111 & 0.1662 & 0 & 0.6667 & 0.9212 & 2.8892 \\
\hline AGE & 5.4190 & 5 & 3.0219 & 1 & 17 & 0.5868 & 3.0513 \\
\hline SIZE & 27.1515 & 26.9614 & 1.5373 & 23.3238 & 31.9220 & 0.4620 & 3.0839 \\
\hline SOLV & 2.3962 & 1.8314 & 1.4086 & 1.0208 & 9.1252 & 2.0974 & 8.0740 \\
\hline LIQ & 1.7421 & 1.4012 & 1.1450 & 0.1843 & 9.4389 & 3.3232 & 18.0163 \\
\hline TURN & 1.1653 & 0.9365 & 0.9173 & 0 & 5.9064 & 1.8458 & 7.4797 \\
\hline
\end{tabular}

Source: Authors' calculation from survey data 
Table 3

Descriptive statistics (Non-HGF group)

\begin{tabular}{|c|c|c|c|c|c|c|c|}
\hline VARIABLES & MEAN & MEDIAN & SD & MIN & MAX & SKEWNESS & KUSTOSIS \\
\hline GROWTH & 0.0423 & 0.0511 & 0.1953 & -1 & 1.4698 & -0.5119 & 1.5266 \\
\hline CEODUAL & 0.3598 & 0 & 0.4800 & 0 & 1 & 0.5838 & 1.3409 \\
\hline CEOSHARE & 0.0592 & 0.0100 & 0.1023 & 0 & 0.7285 & 2.4326 & 9.3783 \\
\hline CEOAGE & 49.7726 & 51 & 7.3192 & 24 & 71 & -0.3481 & 2.7823 \\
\hline CEOEDU & 0.1966 & 0 & 03975 & 0 & 1 & 1.5266 & 3.3308 \\
\hline BLOCK & 0.3414 & 0.3369 & 0.2069 & 0 & 0.85 & 0.0799 & 2.0246 \\
\hline BSIZE & 5.1930 & 5 & 1.7506 & 0 & 11 & -0.9596 & 6.3950 \\
\hline $\mathrm{BOU}$ & 0.1528 & 0 & 0.2360 & 0 & 1 & 1.3527 & 3.6683 \\
\hline BNDEP & 0.2422 & 0.2 & 0.2448 & 0 & 1 & 0.6059 & 2.3544 \\
\hline BGENDER & 0.1468 & 0.1428 & 0.1576 & 0 & 1 & 0.8863 & 3.4509 \\
\hline AGE & 5.4603 & 5 & 3.0152 & 1 & 17 & 0.5179 & 2.9161 \\
\hline SIZE & 26.6782 & 26.5747 & 1.4102 & 20.0441 & 31.6017 & 0.1831 & 3.2233 \\
\hline SOLV & 2.6669 & 2.0040 & 1.7229 & 1.0018 & 9.7372 & 1.8400 & 6.2193 \\
\hline LIQ & 1.9911 & 1.4774 & 1.4615 & 0.2469 & 9.7864 & 2.1881 & 8.3459 \\
\hline TURN & 1.1672 & 0.9737 & 0.8585 & 0 & 5.9951 & 1.8218 & 7.8590 \\
\hline
\end{tabular}

Source: Authors' calculation from survey data

Descriptive statistics show that there are several characteristics of the enterprises that distinguish the HGF group from the other. In addition to the difference in average growth rate (25.44\% compared to $4.23 \%)$, HGF in Vietnam is younger but larger in size; other characteristics (solvency, liquidity, Asset turnover) are all lower than the non-HGF group. These statistical results are consistent with previous researches, such as those of Moreno and Casillas (2007) or Navaretti et al. (2014), in term of age (young companies have higher growth rates), but contradicted in term of size (usually smaller size will have higher growth rate). Other characteristics show the existence of redundant resources and scarcity of financial resources are similar to those of Moreno and Casillas (2007). Regarding the characteristics of the CEO in HGF, it can be seen that the average age, education level, ownership rate, and even the duality are lower than the CEO in the non-HGF. The ownership structure of HGF is less centralized than that of the non-HGF, in which the average ownership of the largest shareholder is $30.6 \%$ compared to $34.1 \%$. Regarding the characteristics of the Board in HGF, it can be seen that the outside members and the independence are lower than the Board in the non-HGF; in terms of size and gender, the average value is not much different.

\subsection{The role of $C E O$ in $H G F$}

In Table 4 the authors presented the regression results of Pooled-OLS, FEM, REM and GMM methods for 3 sample groups: Whole sample, the HGF group, the non-HGF group (Tests for selecting optimal method between Pooled-OLS, FEM or REM, multicollinearity, variance and endogenous are available on request). The regression results from Table 5 show that there was no difference in the impact sign of independent variables related to the characteristics of the CEO on the growth potential of the enterprises in the whole sample and the two groups of enterprises in case of CEODUAL variable; in cases of CEOSHARE and CEOAGE variables, there was a significant difference in the impact sign to the growth potential of the two groups of enterprises. For the control variables, there was no difference in the impact sign to the growth potential in the whole sample and the two groups of enterprises; if so, just a difference in the level of impact.

The age of the CEO in the HGF group is positively correlated with the dependent variable, while the result in the whole sample and in the non-HGF group is the opposite. This result is unexpected, because of the difference with the findings of Navaretti et al. (2014), as well as Phạm Quốc Việt and Lê Quốc Thành (2016), who believe that young CEOs will be the driving force for corporate growth. This result can be explained from Asian culture, which believes that maturity and experience are proportional to age, "a man should be independent at the age of thirty".

CEO duality in the whole sample and in the two groups of enterprises is negatively correlated with the dependent variable. This result is in contrast to the result of Donaldson and Davis (1991), which found a positive correlation between CEO duality and corporate growth; but consistent with the empirical evidence of Daily and Dalton (1992). Dual-position of CEO and the Board Chairman in the joint-stock company helps converge the business development strategy with the daily operating decisions of the CEO, increase the performance and thereby positively affecting the growth potential. In contrast, CEO duality raises the conflict of interest between major shareholders and minority shareholders, especially in a weak legal environment and minority shareholder protection mechanism like in Vietnam. Empirical evidence shows that the possibility of "abuse of power" of major shareholders through the CEO duality mechanism has reduced the growth potential of the enterprises in Vietnam, this negative impact is clearly evident in the HGF group. If interpreted from a theoretical perspective, in Vietnam, representation theory explained the results better than management theory, showing the limitations in enforcing publicity guidelines and transparency in corporate governance. CEO ownership in the HGF group is negatively correlated with the growth potential, which is in contrast to the research results in the whole sample and in the non-HGF group. Reality shows that the incentive to increase the ownership of the CEO is a tool to reduce the negative impact of the representative issue when the CEO is also the representative and the major shareholder in the company. 


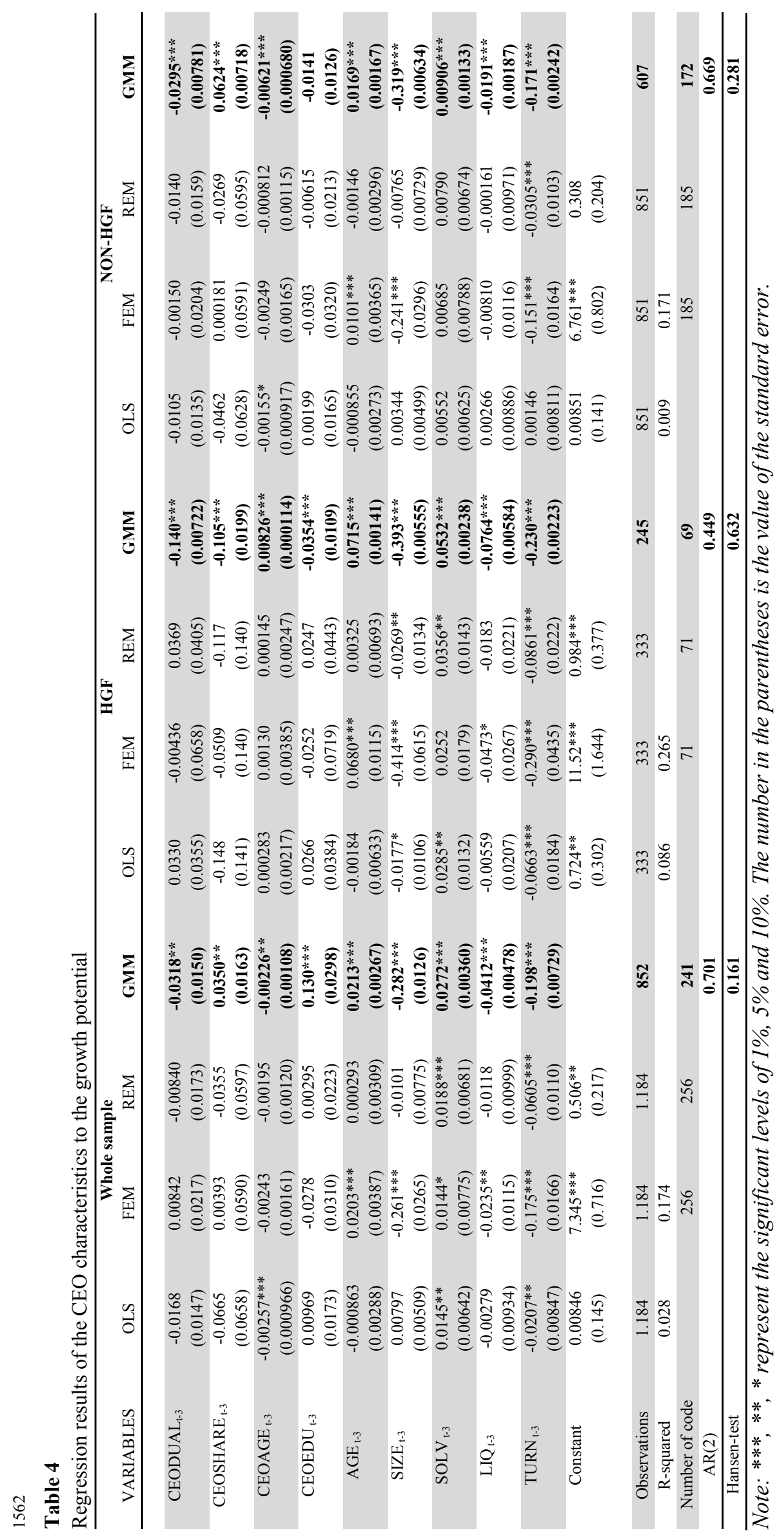


Empirical evidence is provided in the context of low ownership of CEOs in the HGF group, which can lead to speculation that these ownership rates are not enough to create a convergence of interests of the CEOs and shareholders, and need to continue to increase. The education level of the CEO is negatively correlated with the growth potential of the enterprises in the HGF group, but the opposite is found in the whole sample. This result is different from the findings of Phạm Quốc Việt and Lê Quốc Thành (2016) on the sample of FAST 500 Vietnamese enterprises in 2015, but consistent with the result found by Hoxha and Capelleras (2010). On the one hand, conducting postgraduate training contributes to summarizing the practical experiences of the CEO, on the other hand, supporting the CEO to acquire new theories and join the network of managers from fellow students and teachers. The limitation of the data collected is not knowing the training majors of the graduate level (administration - management or specialization). Research results support the point of view that a degree may not be a good measure of managerial or professional competence; and therefore, it should not be a prerequisite for selecting a CEO.

\subsection{The role of the Board in $\mathbf{H G F}$}

The regression results from Table 5 confirm the sign and impact level of the control variables on the dependent variables for the whole data sample and the two groups of enterprises in Table 6. Among the independent variables of the characteristics of the Board, only the board size (BSIZE) variable tends to have the same impact on two groups of enterprises: the HGF and the non-HGF. The remaining independent variables show a difference in sign for the two groups of enterprises, particularly, proportion of outside members (BOU) is negatively correlated with the dependent variable in HGF group, but it is positively correlated with the dependent variable in the whole sample; the independence of the Board (BINDEP) is positively correlated with the dependent variable in HGF group, but it is negatively correlated with the dependent variable in the whole sample; the gender of the Board (BGENDER) is positively correlated with the dependent variable in HGF group, but it is negatively correlated with the growth potential in the remaining enterprise group and in the whole sample. The independence of the Board is a regulation on corporate governance in Vietnam (and many other countries), aiming to increase transparency and not discriminate against shareholders, especially the situation of the major shareholders crowding out the minor shareholders. The research results are consistent with the findings of Ramaswamy et al. (2008), and affirming the correctness of the current legal provisions regarding the proportion of independent members in the Board. The proportion of female members in the Board is positively correlated with the growth potential in the HGF group, but it is negatively correlated with the dependent variable in the non-HGF group and in the whole sample. The research results are consistent with the previous evidence provided by Steffensmeier and Allan (1996), Smith et al. (2006). The proportion of female members in the sample is not high (about 14\%), showing that gender equality is still a problem in countries around the world, especially in East Asia and Southeast Asia, which have a long tradition of "son preference". However, the research results support the management implications of supporting and enabling women to participate in managing and operating businesses more actively. In addition, the size of the Board is positively correlated with the growth potential of the enterprises in both groups: the HGF and the non-HGF. The research results are consistent with the evidence of Ramaswamy et al. (2008) when they found the same impact of the Board size development on both new growth and survival company groups. The data sample reviewed with the average size of the Board is 5.2 people, which is low compared to the regulations (from 3 to 11 people). The increase in the number of the Board members, on the one hand, satisfies the management requirements for public companies and listed companies (increasing the number of non-executive members and independent members), on the other hand, it helps the Board to have enough personnel to fulfill its functions and duties - to be the agency which plans strategies and monitors the execution of CEO. The number of non-executive members in the Board is negatively correlated with the growth potential in the HGF group, but it is positively correlated with the dependent variable in the whole sample. This result is in contrast to the previous empirical evidence of Daily and Dalton (1992), Deakins et al. (2000); and it does not support the current regulations on corporate governance in Vietnam (the ratio of non-executive members in the Board is at least 1/3), which can be explained by the free-rider of nonexecutive members of the Board; and this is the premise for an in-depth research on non-executive members in joint-stock companies in Vietnam.

\subsection{The role of ownership concentration in high growth firms}

The regression results on the relationship between the ownership concentration and the growth potential in Table 5 shows that there is a strong positive correlation in the HGF group between these two variables; whereas, the relationship is negative for the non-HGF group. The results are consistent with the previous findings of Schreyer (2000), Delmar et al. (2003), Bjuggren et al. (2010), and confirming centralized ownership as a factor affecting the growth potential of the enterprises. The results are explained by the Representative Theory, that the owner is highly concentrated the orientation and supervision of major shareholders to the representative is more effective, resulting in excess resources in the enterprises to be more fully exploited, and và resulting in higher growth rates. However, the descriptive statistics from the sample (Table 4) show that the concentration of ownership in HGFs is lower than that of the other group. It shows that concentration of ownership is only a necessary condition, in addition, it also needs many other components of the corporate governance system such as the characteristics of the Board, the characteristics of the CEO and other control variables such as size, age, the existence of excess resources, financial shortage, etc., to create the growth potential of the enterprises. 


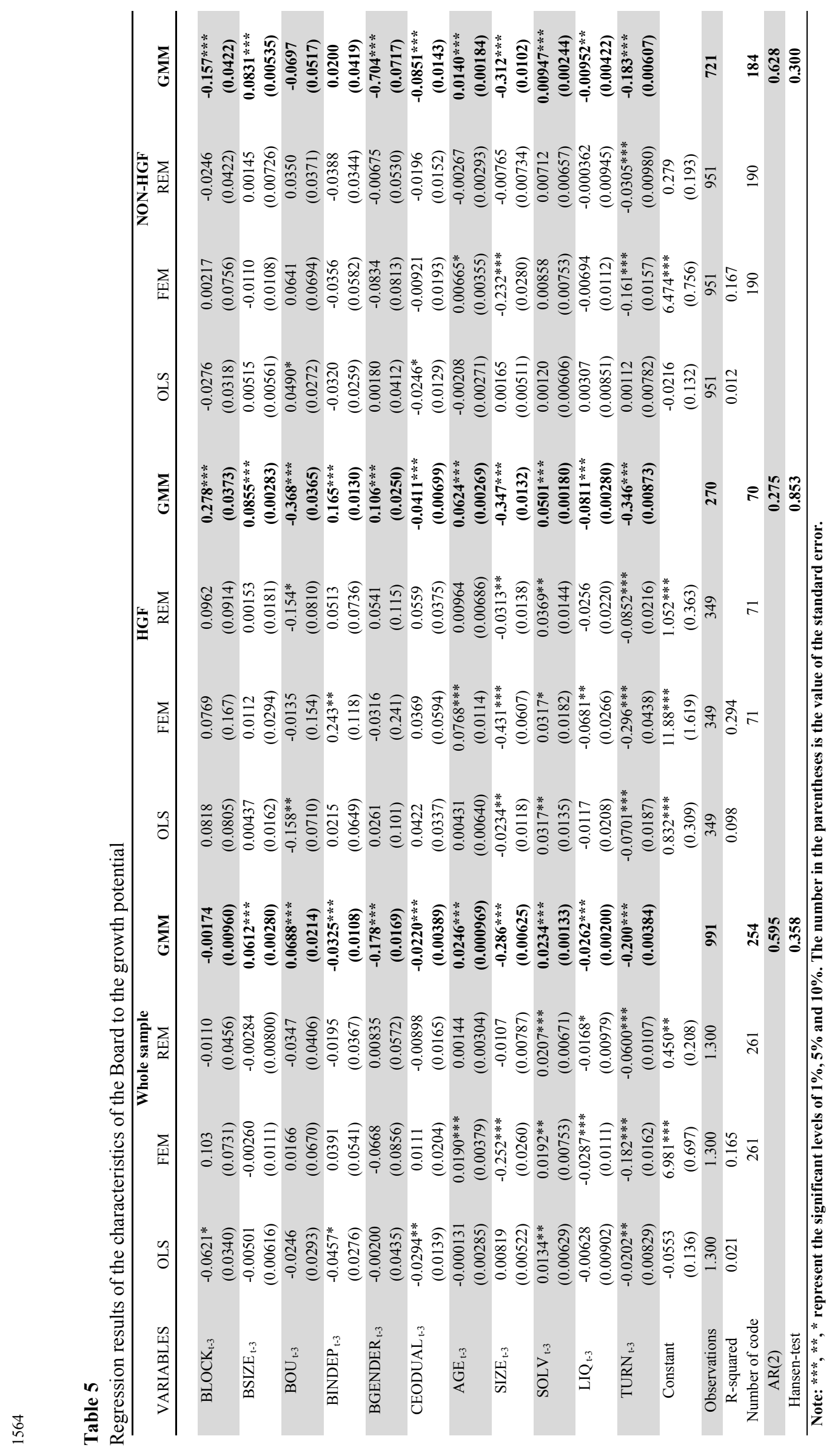




\section{Conclusion and Implication}

The paper has designed to find the empirical evidence on the role of corporate governance in the firm's growth, thereby providing some policy implications for improving corporate governance activities in practice. Using a sample of 241 listed companies on Vietnam's stock market in the period of 2008-2017, divided into 2 groups: high-growth firms and non-highgrowth firms and applying a GMM regression with the dependent variable as 3-year compound growth rate, the study finds evidence of factors that affects the growing ability of corporate governance, namely:

- There is a strong positive correlation in the HGF group between these two variables; whereas, the relationship is negative for the non-HGF group.

- There is a confirmed relationship between the CEO characteristics with the possibility of growth of the enterprise, namely the growth possibility in the HGF group has positive correlation with the age of the CEO, negative correlation with the responsibility, level and possession of the CEO; the growth possibility in the non-HGF group has positive correlation with the owner of the CEO, negative correlation with duality and age of the CEO.

- There is a relationship between the BOD characteristics with the possibility of growth of the enterprise, namely the growth possibility in the HGF group has positive correlation with the size of the BOD, with the proportion of independent members and the proportion of female members in the BOD, and negative correlation with the rate of non-executive membership in the BOD, whereas the growth possibility in the non-HGF group has positive correlation with the size of the BOD, negative correlation with the proportion of female members in the BOD, and negative correlation with the rate of nonexecutive membership in the BOD.

The results of this study affirm the role of the ownership, the BOD and the CEO to the firm's ability to grow, being the basis for policy suggestions aimed at increasing the growth of domestic enterprises, on the other hand, complementing the empirical evidence of the role of corporate governance in the HGF.

\section{References}

Alchian, A. A., \& Demsetz, H. (1972). Production, information costs, and economic organization. The American economic review, 62(5), 777-795.

Almus, M. (2002). What characterizes a fast-growing firm? Applied Economics, 34(12), 1497-1508.

Andersson, S., \& Tell, J. (2009). The relationship between the manager and growth in small firms. Journal of small business and Enterprise Development, 16(4), 586-598.

Baysinger, B. D., \& Butler, H. N. (1985). Corporate governance and the board of directors: Performance effects of changes in board composition. Journal of Law, Economics, \& Organization, 1(1), 101-124.

Becker, G. S. (1975). Front matter, human capital: a theoretical and empirical analysis, with special reference to education. In Human Capital: A Theoretical and Empirical Analysis, with Special Reference to Education, Second Edition (pp. -22-20): NBER.

Beekman, A. V., \& Robinson, R. B. (2004). Supplier partnerships and the small, high growth firm: selecting for success. Journal of Small Business Management, 42(1), 59-77.

Birch, D. L. (1979). The job generation process. MIT: Cambridge, Mass.

Birch, D. L., \& Medoff, J. (1994). Gazelles. Labor markets, employment policy and job creation, 159167.

Bjuggren, C. M., Daunfeldt, S.-O., \& Johansson, D. (2010). Ownership and high-growth firms. Ratio working paper, 147.

Brüderl, J., \& Preisendörfer, P. (2000). Fast-growing businesses: empirical evidence from a German study. International journal of sociology, 30(3), 45-70.

Burgel, O., Fier, A., Licht, G., \& Murray, G. C. (2000). Internationalisation of high-tech start-ups and fast growth-evidence for UK and Germany.

Certo, S. T., Daily, C. M., \& Dalton, D. R. (2001). Signaling firm value through board structure: An investigation of initial public offerings. Entrepreneurship theory and practice, 26(2), 33-50.

Charreaux, G. (2008). À la recherche du lien perdu entre caractéristiques des dirigeants et performance de la firme: gouvernance et latitude managériale. Retrieved from

Daily, C. M., \& Dalton, D. R. (1992). The relationship between governance structure and corporate performance in entrepreneurial firms. Journal of Business Venturing, 7(5), 375-386.

Daily, C. M., \& Thompson, S. S. (1994). Ownership structure, strategic posture, and firm growth: An empirical examination. Family business review, 7(3), 237-249.

Davidsson, P., \& Delmar, F. (1997). High-growth firms: characteristics, job contribution and method observations.

Davidsson, P., Kirchhoff, B., Hatemi-J, A., \& Gustavsson, H. (2002). Empirical analysis of business growth factors using Swedish data. Journal of Small Business Management, 40(4), 332-349.

Deakins, D., O'Neill, E., \& Mileham, P. (2000). The role and influence of external directors in small, entrepreneurial companies: some evidence on VC and non-VC appointed external directors. Venture Capital: An International Journal of Entrepreneurial Finance, 2(2), 111-127.

Delmar, F., Davidsson, P., \& Gartner, W. B. (2003). Arriving at the high-growth firm. Journal of Business Venturing, 18(2), $189-216$.

Donaldson, L., \& Davis, J. H. (1991). Stewardship theory or agency theory: CEO governance and shareholder returns. Australian Journal of management, 16(1), 49-64.

Fried, V. H., Bruton, G. D., \& Hisrich, R. D. (1998). Strategy and the board of directors in venture capital-backed firms. Journal of Business Venturing, 13(6), 493-503.

Gales, L. M., \& Kesner, I. F. (1994). An analysis of board of director size and composition in bankrupt organizations. Journal of business research, 30(3), 271-282. 
Geletkanycz, M. A., \& Hambrick, D. C. (1997). The external ties of top executives: Implications for strategic choice and performance. Administrative Science Quarterly, 654-681.

Glancey, K. (1998). Determinants of growth and profitability in small entrepreneurial firms. International Journal of Entrepreneurial Behavior \& Research, 4(1), 18-27.

Gupta, P. D., Guha, S., \& Krishnaswami, S. S. (2013). Firm growth and its determinants. Journal of Innovation and Entrepreneurship, 2(1), 15.

Halikias, J., \& Panayotopoulou, L. (2003). Chief executive personality and export involvement. Management Decision, 41(4), 340-349.

Hambrick, D. C., \& Crozier, L. M. (1985). Stumblers and stars in the management of rapid growth. Journal of Business Venturing, 1(1), $31-45$.

Hillman, A. J., \& Dalziel, T. (2003). Boards of directors and firm performance: Integrating agency and resource dependence perspectives. Academy of Management Review, 28(3), 383-396.

Hillman, A. J., Keim, G. D., \& Luce, R. A. (2001). Board composition and stakeholder performance: Do stakeholder directors make a difference? Business \& Society, 40(3), 295-314.

Hölzl, W. (2013). Persistence, survival, and growth: a closer look at 20 years of fast-growing firms in Austria. Industrial and corporate change, 23(1), 199-231.

Hoxha, D., \& Capelleras, J.-L. (2010). Fast-growing firms in a transitional and extreme environment: are they different? Journal of small business and Enterprise Development, 17(3), 350-370.

Jensen, M. C., \& Meckling, W. H. (1976). Theory of the firm: Managerial behavior, agency costs and ownership structure. Journal of financial economics, 3(4), 305-360.

Konings, J. (1997). Firm growth and ownership in transition countries. Economics Letters, 55(3), 413-418.

Mateev, M., \& Anastasov, Y. (2010). Determinants of small and medium sized fast growing enterprises in central and eastern Europe: a panel data analysis. Financial Theory and Practice, 34(3), 269-295.

Moreno, A. M., \& Casillas, J. C. (2007). High-growth SMEs versus non-high-growth SMEs: a discriminant analysis. Entrepreneurship and regional development, $19(1), 69-88$.

Muth, M., \& Donaldson, L. (1998). Stewardship theory and board structure: A contingency approach. Corporate Governance: An International Review, 6(1), 5-28.

Navaretti, G. B., Castellani, D., \& Pieri, F. (2014). Age and firm growth: evidence from three European countries. Small Business Economics, 43(4), 823-837.

Noel, A. (1989). Strategic cores and magnificent obsessions: Discovering strategy formation through daily activities of CEOs. Strategic Management Journal, 10(S1), 33-49.

O'Reilly, C. A., \& Chatman, J. (1986). Organizational commitment and psychological attachment: The effects of compliance, identification, and internalization on prosocial behavior. Journal of applied psychology, 71(3), 492.

OECD. (2010). OECD Studies on SMEs and Entrepreneurship High-Growth Enterprises: What Governments Can Do to Make a Difference: Organisation for Economic Co-operation and Development.

Phạm Quốc Việt, \& Lê Quốc Thành. (2016). Hoàn thiện chính sách tài chính hỗ trọ̣ tăng truoơng doanh nghiệp - Phuơng pháp tiếp cận theo trường phái quản trị dựa trên các yếu tố thành công chính yếu (CSFs based management): một nghiên cứu cho các doanh nghiệp phát triển nhanh tại Việt Nam. Đề tài nghiên cứu khoa học cấp Bộ (Bộ Tài chính).

Ramaswamy, V., Ueng, C. J., \& Carl, L. (2008). Corporate governance characteristics of growth companies: An empirical study. Academy of Strategic Management Journal, 7, 21.

Raymond, L., Bergeron, F., \& Blili, S. (2005). The assimilation of E business in manufacturing SMEs: Determinants and effects on growth and internationalization. Electronic Markets, 15(2), 106-118.

Rosenstein, S., \& Wyatt, J. G. (1994). Shareholder wealth effects when an officer of one corporation joins the board of directors of another. Managerial and Decision Economics, 15(4), 317-327.

Schreyer, P. (2000). High-growth firms and employment.

Shleifer, A., \& Vishny, R. W. (1997). A survey of corporate governance. The Journal of Finance, 52(2), 737-783.

Siegel, R., Siegel, E., \& Macmillan, I. C. (1993). Characteristics distinguishing high-growth ventures. Journal of Business Venturing, 8(2), 169-180.

Smith, N., Smith, V., \& Verner, M. (2006). Do women in top management affect firm performance? A panel study of 2,500 Danish firms. International Journal of Productivity and Performance Management, 55(7), 569-593.

Steffensmeier, D., \& Allan, E. (1996). Gender and crime: Toward a gendered theory of female offending. Annual Review of Sociology, 22(1), 459-487.

Storey, D. (2000). A Portrait of Success: The Facts Behind High Growth Companies in the UK (Deloitte \& Touche, London).

Võ Hồng Đức, \& Phan Bùi Gia Thủy. (2013). Quản trị công ty \& hiệu quả hoạt động doanh nghiệp: Minh chứng thực nghiệm từ các công ty niêm yết trên Sở giao dịch Chứng khoán TP.HCM. Tạp chí Phát triển Kinh tế(275), 01-15.

Voulgaris, F., Asteriou, D., \& Agiomirgianakis, G. (2003). The determinants of small firm growth in the Greek manufacturing sector. Journal of Economic Integration, 817-836.

Wernerfelt, B. (1984). A resource based view of the firm. Strategic management journal, 5(2), 171-180.

Wirtz, P. (2011). The cognitive dimension of corporate governance in fast growing entrepreneurial firms. European Management Journal, 29(6), 431-447.

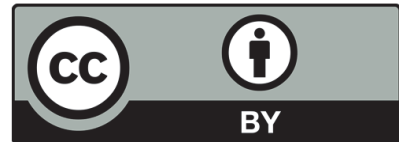

(C) 2020 by the authors; licensee Growing Science, Canada. This is an open access article distributed under the terms and conditions of the Creative Commons Attribution (CC-BY) license (http://creativecommons.org/licenses/by/4.0/). 